\title{
Effect of garlic (Allium sativum) and ginger (Zingiber officinale) extracts on haemato-biochemical parameters and liver enzyme activities in Wistar rats
}

\author{
Joshua Adamu Tende ${ }^{1,}$, Joseph Olusegun Ayo ${ }^{2}$, Aliyu Mohammed ${ }^{1}$, Abdulkadir Umar Zezi ${ }^{3}$ \\ ${ }^{1}$ Department of Human Physiology, Faculty of Medicine, Ahmadu Bello University, Zaria, Nigeria \\ ${ }^{2}$ Department of Veterinary Physiology and Pharmacology, Ahmadu Bello University, Zaria, Nigeria \\ ${ }^{3}$ Department of Pharmacology and Therapeutics, Faculty of Pharmaceutical Sciences, Ahmadu Bello University, Zaria, Nigeria
}

\section{Email address:}

tendejoshua@gmail.com (J. A. Tende)

\section{To cite this article:}

Joshua Adamu Tende, Joseph Olusegun Ayo, Aliyu Mohammed, Abdulkadir Umar Zezi. Effect of Garlic (Allium Sativum) and Ginger (Zingiber Officinale) Extracts on Haemato-Biochemical Parameters and Liver Enzyme Activities in Wistar Rats. International Journal of Nutrition and Food Sciences. Vol. 3, No. 5, 2014, pp. 380-386. doi: 10.11648/j.ijnfs.20140305.13

\begin{abstract}
The study was designed to investigate the separate and combined effects of garlic (Allium sativum) and ginger (Zingiber officinale) on haemato-biochemical parameters and liver enzymes activities in Wistar rats. Rats were assigned into the following groups: Group 1: (Control group $1 \mathrm{ml}$ of distilled water); Group 2: (20 mg/kg of garlic); Group 3: (40 $\mathrm{mg} / \mathrm{kg}$ of garlic); Group 4: (20 mg/kg of ginger); Group 5: (40 mg/kg of ginger); Group 6: (garlic $10 \mathrm{and} \mathrm{ginger} 10 \mathrm{mg} / \mathrm{kg}$ ); Group 7: (garlic 20 and ginger $20 \mathrm{mg} / \mathrm{kg}$ ). The results obtained showed a significantly $(\mathrm{P}<0.05)$ decreased serum ALT, AST and ALP activities in the experimental groups that received combined doses of garlic (10 mg/ $\mathrm{kg})$ and ginger (10 $\mathrm{mg} / \mathrm{kg})$ extract when compared to the control group. There was a significantly decreased $(\mathrm{P}<0.05)$ serum AST and ALP activities in the groups that received $20 \mathrm{mg} / \mathrm{kg}$ of garlic only when compared to that of the control group. There was a significant decrease $(\mathrm{P}<0.05)$ in serum sodium and potassium concentrations in garlic and ginger extract-treated groups when compared to the control group. There was a significant reduction $(\mathrm{P}<0.05)$ in serum concentration of both ionized and total calcium in the extract-treated groups when compared to the control group. The PCV and Hb concentration in garlic and ginger extract treated groups were lower when compared to that of the control group. The RBC count was higher $(\mathrm{P}<0.05)$ in the groups that received garlic and ginger extract when compared to that of the control group. There was a significant change $(\mathrm{P}<0.05)$ in the total $\mathrm{WBC}$ in the groups that received $20 \mathrm{mg} / \mathrm{kg}$ of ginger extract and its combination with garlic at various doses and $40 \mathrm{mg} / \mathrm{kg}$ of ginger and its combination for neutrophils count, when compared to the control group. There was a significant change $(\mathrm{P}<0.05)$ in rats administered with $40 \mathrm{mg} / \mathrm{kg}$ of garlic and its combination for lymphocyte and monocyte count, when compared to the control group. The histological findings in the treated rats showed that the combined doses of garlic and ginger extracts adversely affect the histology of liver tissues. In conclusion, co-administration of garlic and ginger to rats significantly decreased the PCV and Hb concentration, with an elevated RBC count. The liver enzymes activities and serum electrolytes were also altered, hence unsafe for consumption in combined form.
\end{abstract}

Keywords: Garlic, Ginger, Alkaline Phosphatase, Alanine Aminotransferase, Aspartate Aminotransferase, Rats, Leucocytes

\section{Introduction}

Garlic (Allium sativum) and ginger (Zingiber officinale) are widely consumed spices in food, while ginger is also consumed in drink form. The medicinal use of garlic has a long history. Garlic is probably one of the earliest known medicinal plants. Its bulbs (cloves) had been used as a cure- all in ancient Egypt [16]. Potential health benefits of vegetables, in particular garlic (Allium sativum), has its origin in antiquity, but still there is a need to unveil the details of these benefits [16]. Garlic has been reputed to possess therapeutic properties, and is probably the most widely investigated medicinal plant [19]. Despite the numerous therapeutic effects attributed to garlic, the 
chemistry behind its health-promoting effect is poorly understood. Garlic is probably one of the earliest known medicinal plants [18]. Over the centuries, garlic has acquired a special position in the folklore of many cultures as a formidable prophylactic and therapeutic medicinal agent [18]. Recent in vitro studies have confirmed the vasoactive ability of garlic's sulfur compounds, whereby red blood cells convert garlic's organic polysulphides into hydrogen sulphide, a known endogenous cardioprotective vascular cell-signaling molecule [3]. Garlic may also help to prevent cognitive decline by protecting neurones from neurotoxicity and apoptosis, thereby preventing ischaemiaor reperfusion-related neuronal death, and by improving learning and memory retention [7]. Studies have shown that garlic has great potential in inhibiting platelet aggregation and enhancing fibrinolytic activity [26]. Ginger (Zingiber officinale) belongs to Zingiberaceae family [21]. The part of the plant used is rhizome. Ginger is used worldwide as a cooking spice, condiment and herbal remedy [21]. The active components of ginger are reported to stimulate digestion, absorption, relieve constipation and flatulence by increasing muscular activity in the digestive tract [27]. Ginger is reported to be useful in treating inflammation and rheumatism [14]. It stimulates blood circulation throughout the body by powerful stimulatory effect on the heart muscle and by diluting blood [25]. The improved circulation is believed to increase the cellular metabolic activity; thus, contributing to the relief of cramps and tension [15]. Ginger is also known to possess antioxidant properties [13] Jayakumar et al [12]. In human erythrocyte membranes, ginger extracts inhibited lipid peroxidation [28]. In traditional Chinese medicine, ginger is used to improve the flow of body fluids. It stimulates blood circulation throughout the body by exerting powerful stimulatory effect on the heart muscle and by diluting the blood. The improved circulation is believed to increase the cellular metabolic activity, which contributes to the relief of cramps and tension [15]. Several studies have shown the separate effects of $A$. sativum and $Z$. officinale on various haematological and biochemical parameters [19], no record of their combined effects. The aim of the present study was to compare the effects of garlic (A. sativum) and ginger ( $Z$. officinale) extracts in single and combined form on haemato-biochemical parameters and liver enzyme activities in Wistar rats.

\section{Materials and Methods}

\subsection{Management of Experimental Animals}

Strains of Wistar rats of both sexes between the ages of 12 - 16 weeks' old and weighing between 150-200 g were procured from the animal house of the Department of Pharmacology, Ahmadu Bello University, Zaria. The animals were kept in well-aerated laboratory cages in the animal house of the Department of Human Physiology, Ahmadu Bello University, Zaria. They were allowed to acclimatize to the laboratory environment for a period of two weeks before the commencement of the experiment. The rats were given access to standard animal feeds and drinking water ad libitum during the acclimatization period.

\subsection{Collection and Preparation of Plant Extract}

Fresh garlic bulbs and dried rhizome ginger were purchased from Samaru market in Zaria $\left(11^{\circ} 10 \mathrm{~N}, 07^{\circ} 38 \mathrm{E}\right)$ Nigeria. They were identified at the herbarium unit of the Department of Biological Sciences Ahmadu Bello University, Zaria, Nigeria by taxonomist Musa Mohammed, where the voucher numbers (050913 and 0250913) were deposited for garlic and ginger respectively. The bulbs and rhizome were dried under shade and ground into fine powder using laboratory mortar and pestle. The powder (150 g) of garlic and of ginger (208 g) was macerated in cold water for $24 \mathrm{hrs}$. This was then filtered using a filter paper (Whatmann size no. 1) and the filtrate evaporated to dryness on water bath at $40^{\circ} \mathrm{C}$ to a dry residue of garlic and of ginger. The powder was kept in an air-tight bottle in the laboratory until it was reconstituted for administration.

\subsection{Methods}

\subsubsection{Experimental Design}

Thirty five (35) Wistar rats were used in the study. The animals were divided into seven groups of five (5) animals as follows:

Group 1: Served as control and was administered $1 \mathrm{ml}$ of distilled water.

Group 2: Received $20 \mathrm{mg} / \mathrm{kg}$ body weight of garlic.

Group 3: Received $40 \mathrm{mg} / \mathrm{kg}$ body weight of garlic.

Group 4: Administered with $20 \mathrm{mg} / \mathrm{kg}$ body weight of ginger.

Group 5: Received $40 \mathrm{mg} / \mathrm{kg}$ body weight of ginger.

Group 6: Received garlic $10 \mathrm{mg}$ and ginger $10 \mathrm{mg} / \mathrm{kg}$ body weight

Group 7: Received garlic $20 \mathrm{mg}$ and ginger $20 \mathrm{mg} / \mathrm{kg}$ body weight.

All administration was via oral route for four (4) weeks. The study was carried out according to the specifications of the Ahmadu Bello University Animal Ethical Research Committee.

\subsubsection{Collection and Preparation of Samples}

Four weeks after the treatment period all rats were fasted for 12 hours and sacrificed after mild anaesthesia with chloroform, soaked in cotton wool placed in anaesthetic box and covered with lid. Blood sample $(5 \mathrm{ml})$ was drawn from the heart of each sacrificed animal from all groups by cardiac puncture. Blood samples were collected in full Ethylenediaminetetraacetic acid (EDTA) bottles for the determination of haematological parameters. Other blood samples $(5 \mathrm{ml})$ were collected in plain tubes and were allowed to clot. The serum was separated by centrifugation using Denley BS400 centrifuge (England) at $1,968 \times \mathrm{g}$ for 10 minutes. The serum collected was used to determine lipid profile, activities of liver enzymes and concentrations 
of serum electrolytes. Liver and kidney tissues were equally dissected out and washed in ice-cold saline immediately for histological studies.

\subsection{Determination of Activities of Serum Liver Enzymes}

The activities of serum enzymes, alanine aminotransferase (ALT), aspartate aminotransferase (AST) and alkaline phosphatase (ALP) were determined spectrophotometrically, using enzymatic colometric assay kits according to the laboratory procedures of Randox Laboratories Limited kits, United Kingdom.

\subsubsection{Determination of Activity of Serum Alanine Aminotransferase Activity}

This was carried out by the method of Berg et al. [4]. Briefly, $1000 \mu \mathrm{l}$ of the reagent was added to $100 \mu \mathrm{l}$ of the serum sample, then mixed and incubated at $37^{\circ} \mathrm{C}$ for 1 minute. The change in absorbance of the sample was measured spectrophotometrically at wavelength of $590 \mathrm{~nm}$ during three minutes.

The ALT activity $(\mathrm{IU} / \mathrm{L})=$ Absorbance of sample/Absorbance of standard $\times$ Concentration of standard

\subsubsection{Determination of Serum Aspartate Aminotransferase Activity}

This was carried out by the method as described by Bergmeyer et al. [5]. Briefly, $20 \mu \mathrm{L}$ sample was transferred into each well and Kept at the desired temperature. Working reagents for sample and standard wells were prepared by mixing for each well, $200 \mu \mathrm{L}$ assay buffer, 1 $\mu \mathrm{L}$ cofactor, $1 \mu \mathrm{L}$ enzyme mix and $4 \mu \mathrm{L}$ NADH. This was warmed to the desired temperature. Blank reagent for the blank well was also prepared by mixing $200 \mu \mathrm{L}$ assay buffer, $1 \mu \mathrm{L}$ cofactor, $1 \mu \mathrm{L}$ enzyme mix and $4 \mu \mathrm{L}$ water and warmed to the desired temperature. $200 \mu \mathrm{L}$ working reagent was added to the standard and sample wells. Immediately tap plate was mixed, incubated at the desired temperature and read the absorbance at $340 \mathrm{~nm}$ at $5 \mathrm{~min}$ and at $10 \mathrm{~min}$.

The ALT activity $(\mathrm{IU} / \mathrm{L})=$ Absorbance of sample/Absorbance of standard $\times$ Concentration of standard.

\subsubsection{Determination of Activity of Serum Alkaline Phosphatase Activity}

This was estimated by the method described by Bowers and $\mathrm{McComb}$ [8]. Briefly, $1000 \mu \mathrm{L}$ of the reagent was added to $100 \mu \mathrm{L}$ of the serum sample, mixed and incubated at $37^{\circ} \mathrm{C}$ for 1 minute. The change in absorbance of the sample was measured spectrophotometrically at the wavelength of $590 \mathrm{~nm}$ during three minutes.

The ALT activity $(\mathrm{IU} / \mathrm{L})=$ Absorbance of sample/Absorbance of standard $\times$ Concentration of standard

\subsection{Determination of Serum Electrolytes}

Serum sodium and potassium ions were measured by the flame photometry (Model 410 Flame Photometer, Sherwood Scientific Ltd., England) method of Vogel [30], and bicarbonate ion was determined using the titration method of Segal [24]. Chloride ion was analysed using the method of Schales and Schales [23]. Calcium ion was determined according to the laboratory procedure of Randox Laboratories Limited kits, England, United Kingdom.

\subsection{Determination of Haematological Parameters}

Haematological parameters of total and differential WBC counts, RBC count, packed cell volume, haemoglobin concentration were determined by the method of Dacie and Lewis [9].

\subsection{Histopathological Studies}

The liver and kidney tissues dissected were washed in ice-cold saline immediately. A portion of each tissue was fixed in $10 \%$ neutral formal saline fixative solution for histological studies. After fixation, tissues were embedded in paraffin. Sections were cut at the thickness of $5 \mu \mathrm{m}$ and various sections were stained with haematoxylin and eosins as described by Galozhger and Kocloff [11]. The slides were viewed at the magnification of $x 250$ and photomicrographs taken.

\subsection{Statistical Analysis}

Data were expressed as mean \pm SEM. The data obtained were analyzed using one-way analysis of variance (ANOVA). Tukey's multiple comparison post-hoc test was used to determine the level of significance between control and experimental groups. Values of $\mathrm{P}<0.05$ were considered as significant [10].

\section{Results}

There was no significant $(\mathrm{P}>0.05)$ difference in the activities of serum ALT and AST in the experimental group, administered with various doses of ginger and garlic as well as their combination, when compared to those of the control group (Figures 1 and 2). There was also no significant $(\mathrm{P}>0.05)$ change in activities of serum ALP in the group that received 20 and $40 \mathrm{mg} / \mathrm{kg}$ of garlic, respectively, when compared to the control group. The serum activity of serum ALP in the groups treated with 20 and $40 \mathrm{mg} / \mathrm{kg}$ of ginger and their combination were higher when compared to their control groups, respectively (Figure 3). 


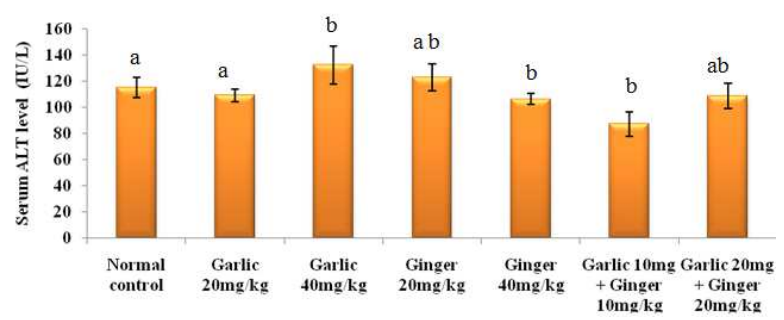

$\mathrm{a}, \mathrm{b}=$ Means with different letters are significantly $(\mathrm{P}<0.05)$ different

Figure 1. Effects of garlic and ginger on activity of serum alanine aminotransferase (ALT) in Wistar rats. Bar represent mean \pm SEM for six animals in each group

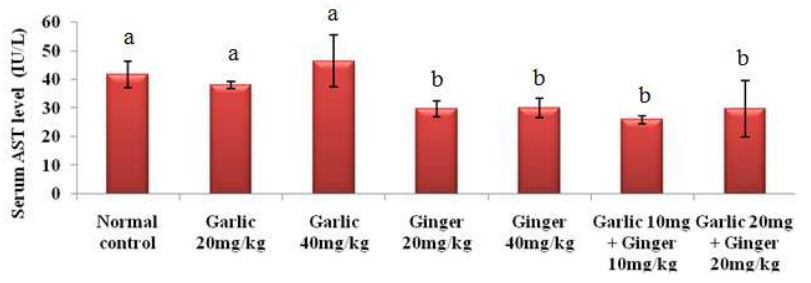

$\mathrm{a}, \mathrm{b}=$ Means with different letters are significantly $(\mathrm{P}<0.05)$ different

Figure 2. Effects of garlic and ginger on activities of serum aspartate aminotransferase in Wistar rats. Bar represent mean \pm SEM for six animals in each group

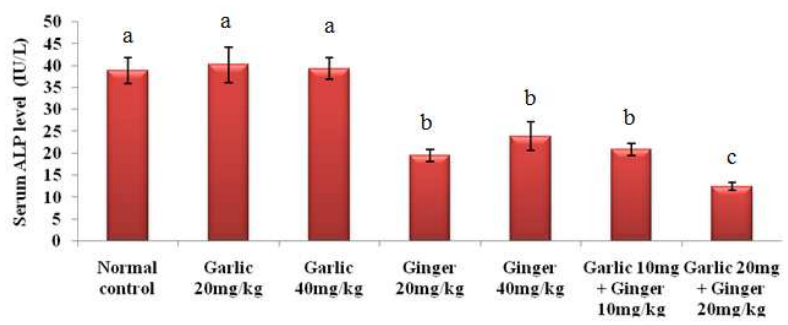

Bar represents mean \pm SEM for six animals in each group a,b,c $=$ Means with different letters are significantly $(\mathrm{P}<0.05)$ different

Figure 3. Effects of garlic and ginger on activity of serum alkaline phosphatase in Wistar rats.

Table 1 shows the mean values of serum calcium and electrolyte Concentration control and experimental groups administered with graded doses of garlic and ginger and their combination. There was a significant $(\mathrm{P}<0.05)$ decrease in serum sodium concentration while serum potassium concentration rose significantly $(\mathrm{P}<0.05)$ in garlic and gingerextract treated groups, when compared to the control group. The concentration of serum chloride ion increased $(\mathrm{P}<0.05)$ only in groups given 20 and $40 \mathrm{mg} / \mathrm{kg}$ of garlic, when compared to the control group. The serum bicarbonate ion concentration in all groups administered with different doses of garlic and ginger extract did not differ, when compared to the control group. There was a significant $(\mathrm{P}<0.05)$ reduction in serum concentration of both ionized and total calcium in the extract-treated groups, when compared to the control group.

Table 2 shows the mean values packed cell volume, haemoglobin concentration and red cell count of control and experimental groups, administered with graded doses of garlic and ginger and their combination. There was a significant $(\mathrm{P}<$ $0.05)$ reduction in packed cell volume and haemoglobin concentration in garlic and ginger extract-treated groups, when compared to control group. However, the RBC count rose significantly $(\mathrm{P}<0.05)$ in the groups that received garlic and ginger extract, when compared to the control group.

There was no significant $(\mathrm{P}<0.05)$ change in total white blood cell count and neutrophil count in the groups treated with 20 or $40 \mathrm{mg} / \mathrm{kg}$ of garlic extract. There was a significant difference $(\mathrm{P}<0.05)$ in total white blood cell counts in the groups that received $20 \mathrm{mg} / \mathrm{kg}$ of ginger extract and their combination with garlic at various doses and neutrophil count in those given $40 \mathrm{mg} / \mathrm{kg}$ of ginger and its combination when compared to the control group (Table 3). The lymphocyte count was significantly $(\mathrm{P}<0.05)$ higher in rats administered with $40 \mathrm{mg} / \mathrm{kg}$ of garlic and its combination; and in rats treated with garlic 20 plus ginger $20 \mathrm{mg} / \mathrm{kg}$. The monocyte count was higher $(\mathrm{P}<0.05)$ than that of the control group (Table 3$)$.

The histological features of the liver showed normal cytoarchitecture of the liver with the hepatocytes and central vein clearly seen (Plates 1-5). While (Plates 6-7) garlic (10 mg/kg) + ginger $(10 \mathrm{mg} / \mathrm{kg})$ showed a distortion in the hepatocytes with the central vein congested, suggesting a damaged liver tissue.

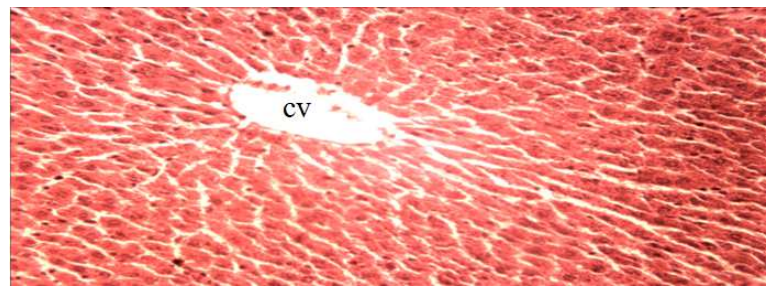

Plate 1. Photomicrograph of a section of liver of rats administered with dsistilled water showing normal architecture of central vein $(\mathrm{CV})$, cords of hepatocytes $(H)$ are distinct and essentially normal, cytoplasm not vacuolated and sinusoids arranged in fairly radial position in relation to the central vein (H\&E Stained $x 250)$.

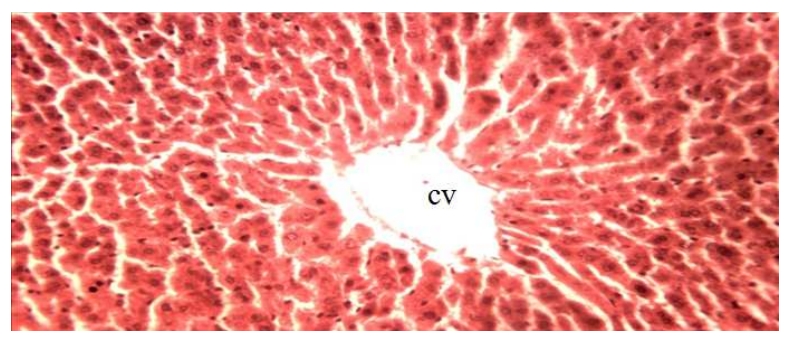

Plate 2. Photomicrograph of a section of liver of rats administered with aqueous extract of garlic $20 \mathrm{mg} / \mathrm{kg}$. Note the normal architecture of central vein $(\mathrm{CV})$, intact hepatocytes $(H)$ and sinusoids, arranged in fairly radial position in relation to the central vein ( $H \& E$ Stained $x 250)$.

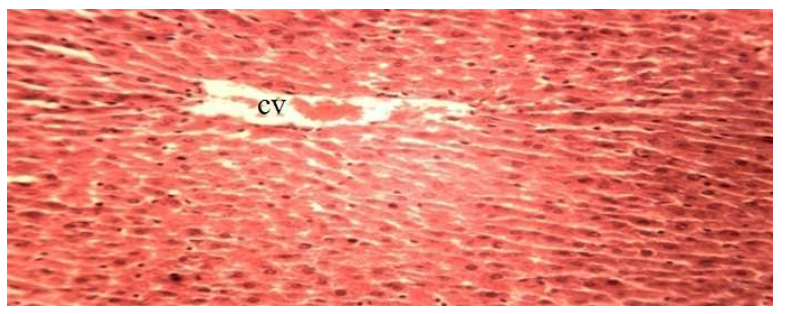

Plate 3. Photomicrograph of a section of liver from normal Wistar rats administered with aqueous extract of garlic $40 \mathrm{mg} / \mathrm{kg}$. Note normal architecture of central vein (CV), cord of hepatocytes $(H)$ well preserved, no fatty degeneration and change and sinusoids arranged in fairly radial position in relation to the central vein (H\&E Stained $x 250)$. 


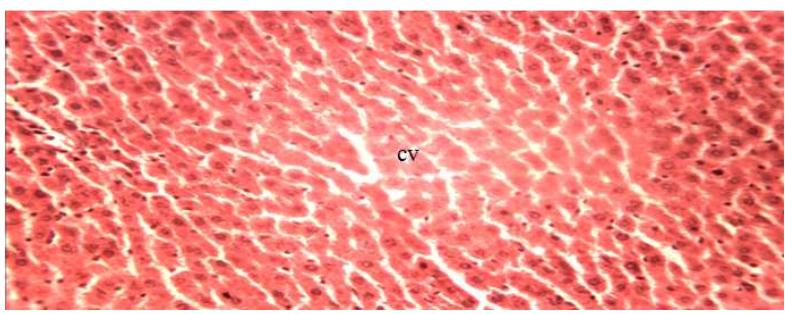

Plate 4. Photomicrograph of a section of liver of rat administered with aqueous extract of ginger $20 \mathrm{mg} / \mathrm{kg}$. Note normal architecture of central vein $(\mathrm{CV})$, cord of hepatocytes $(\mathrm{H})$ and well preserved, no fatty degeneration and change and sinusoids are well demarcated (H\&E Stained $x$ 250).

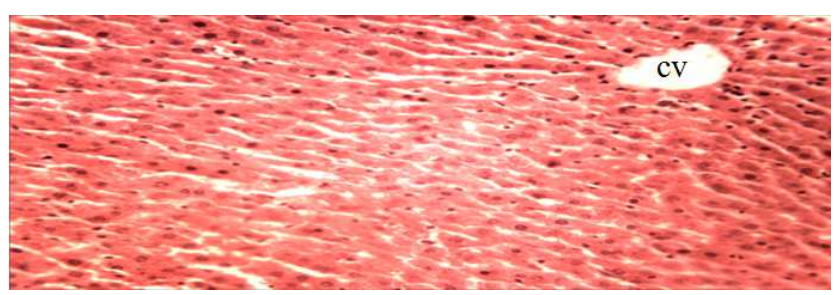

Plate 5. Photomicrograph of a section of liver of rat administered with aqueous extract of ginger $40 \mathrm{mg} / \mathrm{kg}$. Note normal architecture of central vein $(\mathrm{CV})$, cord of hepatocytes $(H)$ well preserved no fatty degeneration and change, the sinusoids arranged in fairly radial position in relation to the central vein ( $H \&$ E Stained $x 250)$.

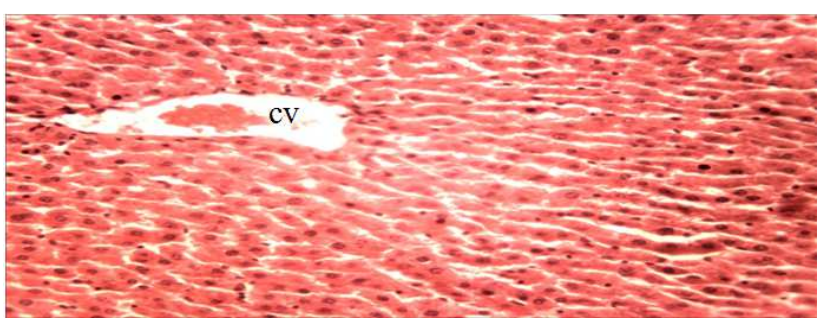

Plate 6. Photomicrograph of a section of liver of rat administered with aqueous extract of garlic $20 \mathrm{mg} / \mathrm{kg}$ and ginger $20 \mathrm{mg} / \mathrm{kg}$. Note distorted cytoarchitecture of central vein $(\mathrm{CV})$ and of the hepatocytes $(\mathrm{H})$ with fatty degeneration ( $H \&$ E Stained X 250).

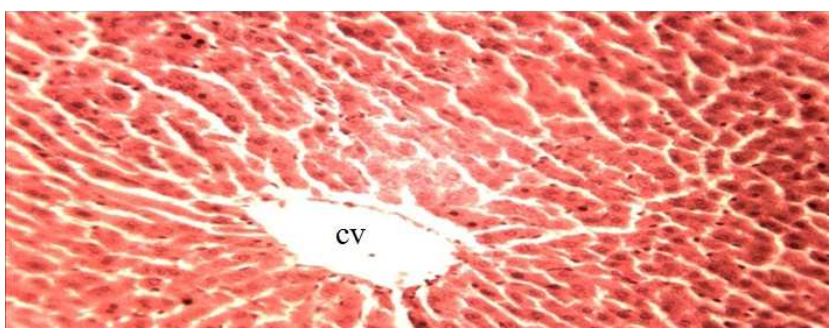

Plate 7. Photomicrograph of a section of liver of rat administered with aqueous extract of garlic $20 \mathrm{mg} / \mathrm{kg}$ and ginger $20 \mathrm{mg} / \mathrm{kg}$. Note distorted cytoarchitecture of central vein $(\mathrm{CV})$ and of the hepatocytes $(\mathrm{H})$ with fatty degeneration ( $H \&$ E Stained X 250).

Table 1. Effectsof Garlic (Allium sativum) and Ginger (Zingiber officinale) on Serum Calcium and Electrolyte Concentration in Wistar Rats

\begin{tabular}{|c|c|c|c|c|c|c|c|}
\hline Treatment & $\mathbf{K}^{+}(\mathbf{m m o l} / \mathbf{L})$ & $\mathrm{Na}^{+}(\mathrm{mmol} / \mathrm{L})$ & $\mathrm{Cl}^{-}(\mathrm{mmol} / \mathrm{L})$ & $\begin{array}{l}\mathrm{HCO}_{3}^{-} \\
(\mathrm{mmol} / \mathrm{L})\end{array}$ & $\begin{array}{l}\text { Ionized Calcium } \\
(\mathrm{mmol} / \mathrm{L})\end{array}$ & $\begin{array}{l}\text { Non-ionized } \\
\text { Calcium }(\mathrm{mmol} / \mathrm{L})\end{array}$ & $\begin{array}{l}\text { Total calcium } \\
(\mathrm{mmol} / \mathrm{L})\end{array}$ \\
\hline $\begin{array}{l}\text { Normal + distilled } \\
\text { Water }\end{array}$ & $4.68 \pm 0.19^{\mathrm{a}}$ & $141.52 \pm 1.18^{\mathrm{a}}$ & $103.36 \pm 2.36^{\mathrm{a}}$ & $17.80 \pm 0.86^{\mathrm{a}}$ & $0.86 \pm 0.038^{\mathrm{a}}$ & $1.096 \pm 0.067^{\mathrm{a}}$ & $1.96 \pm 0.074^{\mathrm{a}}$ \\
\hline Garlic $20 \mathrm{mg} / \mathrm{kg}$ & $6.20 \pm 0.18^{b}$ & $119.03 \pm 1.70^{b}$ & $88.34 \pm 3.62^{b}$ & $22.03 \pm 0.74^{\mathrm{a}}$ & $0.61 \pm 0.033^{\mathrm{b}}$ & $1.014 \pm 0.023^{\mathrm{a}}$ & $1.62 \pm 0.028^{b}$ \\
\hline Garlic $40 \mathrm{mg} / \mathrm{kg}$ & $6.96 \pm 0.23^{b}$ & $119.03 \pm 1.69^{b}$ & $87.13 \pm 2.16^{\mathrm{b}}$ & $23.82 \pm 1.43^{\mathrm{a}}$ & $0.64 \pm 0.027^{b}$ & $0.878 \pm 0.078^{b}$ & $1.51 \pm 0.068^{\mathrm{b}}$ \\
\hline Ginger $20 \mathrm{mg} / \mathrm{kg}$ & $6.87 \pm 0.26^{b}$ & $125.79 \pm 4.90^{b}$ & $90.35 \pm 4.26^{\mathrm{a}}$ & $21.18 \pm 0.79^{\mathrm{a}}$ & $0.60 \pm 0.038^{b}$ & $0.842 \pm 0.062^{b}$ & $1.45 \pm 0.046^{\mathrm{b}}$ \\
\hline Ginger $40 \mathrm{mg} / \mathrm{kg}$ & $6.68 \pm 0.28^{b}$ & $122.22 \pm 2.97^{b}$ & $93.70 \pm 2.06^{\mathrm{a}}$ & $23.17 \pm 1.71^{\mathrm{a}}$ & $0.59 \pm 0.035^{b}$ & $0.844 \pm 0.074^{\mathrm{b}}$ & $1.44 \pm 0.063^{\mathrm{b}}$ \\
\hline $\begin{array}{l}\text { Garlic } 10 \mathrm{mg}+ \\
\text { Ginger } 10 \mathrm{mg} / \mathrm{kg}\end{array}$ & $7.44 \pm 0.28^{b}$ & $118.55 \pm 5.24^{b}$ & $92.36 \pm 2.42^{\mathrm{a}}$ & $22.97 \pm 1.64^{\mathrm{a}}$ & $0.64 \pm 0.027^{b}$ & $0.854 \pm 0.093^{\mathrm{b}}$ & $1.49 \pm 0.097^{\mathrm{b}}$ \\
\hline $\begin{array}{l}\text { Garlic } 20 \mathrm{mg}+ \\
\text { Ginger } 20 \mathrm{mg} / \mathrm{kg}\end{array}$ & $7.94 \pm 0.27^{b}$ & $94.19 \pm 21.01^{b}$ & $90.58 \pm 3.44^{\mathrm{a}}$ & $25.93 \pm 1.25^{\mathrm{a}}$ & $0.64 \pm 0.070^{b}$ & $0.89 \pm 0.086^{b}$ & $1.53 \pm 0.122^{b}$ \\
\hline
\end{tabular}

$\mathrm{a}, \mathrm{b}=$ Means with different superscripts $(\mathrm{a}, \mathrm{b})$ are significantly different $(\mathrm{P}<0.05)$ when compared to control group

Table 2. Effects of Garlic (Allium sativum) and Ginger (Zingiber officinale) on Packed cell Volume (PCV), Red Blood Cell Count (RBC) and Haemoglobin (Hb) in Wistar Rats

\begin{tabular}{llll}
\hline Treatment & PCV (\%) & RBC (10 $\left.{ }^{12} / \mathbf{L}\right)$ & Hb (g/dL) \\
\hline Normal control+ Distilled Water & $54.80 \pm 1.77^{\mathrm{a}}$ & $4.21 \pm 0.078^{\mathrm{a}}$ & $18.26 \pm 0.58^{\mathrm{a}}$ \\
Garlic $20 \mathrm{mg} / \mathrm{kg}$ & $43.00 \pm 1.79^{\mathrm{b}}$ & $4.99 \pm 0.268^{\mathrm{b}}$ & $14.34 \pm 0.59^{\mathrm{b}}$ \\
Garlic $40 \mathrm{mg} / \mathrm{kg}$ & $36.40 \pm 2.292$ & $5.11 \pm 0.194^{\mathrm{b}}$ & $12.14 \pm 0.76^{\mathrm{b}}$ \\
Ginger $20 \mathrm{mg} / \mathrm{kg}$ & $36.60 \pm 2.16^{\mathrm{b}}$ & $5.29 \pm 0.077^{\mathrm{b}}$ & $12.19 \pm 0.72^{\mathrm{b}}$ \\
Ginger $40 \mathrm{mg} / \mathrm{kg}$ & $37.40 \pm 1.25^{\mathrm{b}}$ & $5.24 \pm 0.066^{\mathrm{b}}$ & $12.45 \pm 0.41^{\mathrm{b}}$ \\
Garlic $10 \mathrm{mg}+$ Ginger $10 \mathrm{mg} / \mathrm{kg}$ & $33.20 \pm 1.11^{\mathrm{b}}$ & $5.27 \pm 0.107^{\mathrm{b}}$ & $11.04 \pm 0.37^{\mathrm{b}}$ \\
Garlic $20 \mathrm{mg}+$ Ginger $20 \mathrm{mg} / \mathrm{kg}$ & $35.60 \pm 0.68^{\mathrm{b}}$ & $5.51 \pm 0.079^{\mathrm{b}}$ & $11.87 \pm 0.23^{\mathrm{b}}$ \\
\hline
\end{tabular}

\footnotetext{
$\mathrm{a}, \mathrm{b}=$ Means with different superscripts $(\mathrm{a}, \mathrm{b})$ are significantly different $(\mathrm{P}<0.05)$ when compared to control group
} 
Table 3. Effects of Garlic (Allium sativum) and Ginger (Zingiber officinale) on Total and Differential (White Blood Cell count) (WBC) in Wistar rats

\begin{tabular}{lllll}
\hline Treatment Given & WBC $\times \mathbf{1 0} \mathbf{9}^{\mathbf{L}}$ & Neutrophils $\mathbf{( \% )}$ & Lymphocytes (\%) & Monocytes $(\%)$ \\
\hline Normal + distilled Water & $12.03 \pm 0.28^{\mathrm{a}}$ & $28.40 \pm 1.03^{\mathrm{a}}$ & $57.0 \pm 2.56^{\mathrm{a}}$ & $5.67 \pm 0.67^{\mathrm{a}}$ \\
Garlic 20mg/kg & $10.29 \pm 0.67^{\mathrm{a}}$ & $30.40 \pm 3.01^{\mathrm{a}}$ & $63.20 \pm 2.87^{\mathrm{a}}$ & $6.40 \pm 0.68^{\mathrm{a}}$ \\
Garlic 40mg/kg & $9.27 \pm 1.22^{\mathrm{a}}$ & $32.67 \pm 3.71^{\mathrm{a}}$ & $66.0 \pm 1.00^{\mathrm{b}}$ & $4.60 \pm 0.40^{\mathrm{a}}$ \\
Ginger 20mg/kg & $6.38 \pm 0.27^{\mathrm{b}}$ & $34.00 \pm 2.45^{\mathrm{a}}$ & $60.40 \pm 2.86^{\mathrm{a}}$ & $5.60 \pm 0.60^{\mathrm{a}}$ \\
Ginger 40mg/kg & $5.98 \pm 0.36^{\mathrm{b}}$ & $39.00 \pm 2.79^{\mathrm{b}}$ & $61.67 \pm 3.33^{\mathrm{a}}$ & $4.00 \pm 0.89^{\mathrm{a}}$ \\
Garlic 10mg + Ginger 10mg/kg & $5.39 \pm 0.38^{\mathrm{b}}$ & $35.40 \pm 2.21^{\mathrm{b}}$ & $73.00 \pm 4.12^{\mathrm{b}}$ & $5.60 \pm 0.40^{\mathrm{a}}$ \\
Garlic 20mg + Ginger 20mg/kg & $4.31 \pm 0.75^{\mathrm{b}}$ & $32.20 \pm 1.28^{\mathrm{a}}$ & $80.00 \pm 5.94^{\mathrm{b}}$ & $6.80 \pm 0.74^{\mathrm{b}}$ \\
\hline
\end{tabular}

${ }^{\mathrm{a}, \mathrm{b}}=$ Means with different superscripts $(\mathrm{a}, \mathrm{b})$ are significantly different $(\mathrm{P}<0.05)$ when compared to control group

\section{Discussion}

The present study investigated liver function profile, hematological and biochemical effects of garlic and ginger in Wistar rats. The liver is the main target organ of acute toxicity when exposed to the foreign substances. When these substances are absorbed in intestines they are metabolized to other compounds which may or may not be hepatotoxic to the rats [22]. In this study, the liver histology revealed evidence of distorted cyto-architecture of the liver cells in animals treated with combination of garlic and ginger extracts (Plate 6-7). This was further demonstrated by the decrease in liver enzyme activities in the groups treated with combined doses of garlic and ginger extracts respectively. This suggests that combination of garlic and ginger is toxic to the liver. Histological findings in the groups treated with single doses of garlic and ginger respectively showed a well preserved structural integrity of liver tissues with no area of necrosis and fatty degeneration in the liver tissues (Plate 2-5). This suggests the nondeleterious effects of these single doses of garlic and ginger extracts in rats [1].

A marked decrease in serum sodium concentration observed during the present study may be due to a change in glomerular filteration rate and/or renal blood flow [31] or interference with aldosterone secretion and/or action on the distal tubules [20] or interference with adrenergic sodium handling [31] caused by garlic and ginger administration as well as their combination. There was also significantly elevated $(p<0.05)$ serum potassium level in the groups administered with all dose garlic and ginger extract and its combination respectively when compared to the control group. The present finding suggests that the rise in the concentration of potassium may be due to the alteration in potassium transport produced by extracts [31].

The assessment of haematological parameters could be used to reveal the deleterious effect of foreign compounds, toxins, chemicals and plant extracts on the blood constituents of animals. It is also used to determine possible alterations in the levels of biomolecules such as enzymes, metabolic products, haematology, normal functioning and histology of the organs [17]. The study also showed that daily administration of animals with various doses of garlic and ginger significantly decreased packed cell volume and haemoglobin concentration. This showed that garlic and ginger are toxic to red blood cells. This finding is in agreement with the results obtained by Banerjee and Maulik [2] that prolonged feeding of rats with garlic, and probably ginger, may cause anaemia, weight loss and stunted growth in rats. However in this study, the weight of the animals was not determined. The results of the present study also showed that administration of various doses of garlic and ginger extracts to the animals significantly elevated the red blood cell count. The results suggest that garlic and ginger components may compete with haemoglobin in the red blood cell for oxygen, resulting in hypoxia, which then stimulates red blood cell production. There was a significantly increased neutrophil and lymphocyte count in rats that received garlic 40 and ginger $40 \mathrm{mg} / \mathrm{kg}$ and their combination. The monocyte count was significantly elevated in rats administered with $20 \mathrm{mg} / \mathrm{kg}$ of garlic and ginger combination. This observation supports the findings of Sumiyoshi [29] and Bjarnsholt et al. [6] that garlic, and probably ginger, stimulates immune functions in rats.

The present study showed a significant decrease in total leucocyte count due to the combination of garlic and ginger. It was concluded that the consumption of garlic and ginger in combined form decreased the liver enzyme activities, it is toxic to the liver, decreased leucocyte count, $\mathrm{PCV}$ and $\mathrm{Hb}$; hence it should be discouraged.

\section{Acknowledgement}

The authors of this work wish to acknowledge the technical assistance of Mr. Bambe, A. O., Mr. J. E Toryila, Mallam Bala Mohammed, Mallam Saleh, M .N. and Mr. Yusuf, Inuwa of the Department of Human Physiology, Ahmadu Bello University, Zaria, Nigeria towards the success of this research work.

\section{References}

[1] Banerjee SK, Maulik M, Manchanda SC, Dinda AK, Das TK, Maulik SK. 2001. Garlic-induced alteration in rat liver and kidney Morphology and associated changes in endogenous antioxidant status. Food Chemical Toxicology 39: 793-7. 
[2] Banerjee SK, Maulik SK. 2002. Effect of garlic on cardiovascular disorders: a review. Nutrition Journal 1:4-14

[3] Benavides GA, Squadrito GL, Mills RW, Patel HD, Isbell TS, Patel RP, Darley-Usmar VM, Doeller JE, Kraus DW. 2007. Hydrogen sulfide mediates the vasoactivity of garlic. Proceedings of the National Academy of Sciences of the U.S.A. 104: 7977-7982.

[4] Berg, JM, Tymoczko JL, Stryer, L. 2006. Biochemistry. W.H. Freeman. pp. 656-660.

[5] Bergmeyer HU, Scheibe P, Wahlefeld AW. 1978. Optimization of methods for aspartate aminotransferase and alanine aminotransferase. Clinical Chemistry 24(1): 58-73.

[6] Bjarnsholt T, Ostrup JP, Rasmussen TB, Christophersen L, Calum H, Hougen HP, Rygaard J, Mosenn C, Ebert L, Hhalby N, Gisvkovs NM. 2005. Garlic blocks quorum sensing and promotes rapid clearing of pulmonary Pseudomonas aeruginosa infections. Microbiology $151: 3878-3880$.

[7] Borek C. 2006. Garlic reduces dementia and heart-disease risk. Journal of Nutrition 136 (3 Suppl): 810-812.

[8] Bowers GNJ, McComb RB. 1966. A continuous spectrophotometric method for measurement the activity of serum alkaline phosphatase. Clinical Chemisty 12:73.

[9] Dacie JV, Lewis S. 1991. Practical Hematology. 7th Edn., Churchhill Livingstone, New York, 50-56.

[10] Duncan RC, Knapp RG, Miller MC. 1977. Test of hypothesis in population means. In: Introductory Biostatistics for the health sciences. John Wiley and Sons Inc. NY 71-96.

[11] Galozhger AE, Kocloff EN. 1971. Essential Practical Micro technique. 2ndEdn.,Lee and Febizer, Philadelphia, pp: 77.

[12] Jayakumar SM, Nalini N, Venugopal M. 1999. Antioxidant activity of ginger (Zingiber officinale Roscoe.) in rats fed a high fat diet. Medical Science Research 27: 341-344.

[13] Kikuzaki H, Nakatani N. 1993. Antioxidant effect of some ginger constituents, Journal of Food Science 58(6): 1407 1410 .

[14] Kiuchi, F., S. Iwakami, M. Shibuya, F. Hanaoka and U. Sankawa,1992.Inhibition of prostaglandin and leukotriene biosynthesis by gingerols and diaryl heptanoids. Chemical and Pharmaceutical Bulletin 40: (2)387-391.

[15] Kobayashi M, Tshida Y, Shoji N, Okizumi Y. 1988. Cardiotonic action of gingerol, an activator of the $\mathrm{Ca}^{2+}$ pumping adenosine triphosphatase ofsarcoplasmic reticulum,in guinea pig atrial muscle. Journal of Pharmacology and Experimental Therapeutics 246: 667673.

[16] Lewis W, Elvin-Lewis M. 2003. Medical Botany: Plants Affecting Human Health 2nd ed. New York: Wiley.

[17] Magalhaes P, Appell H, Duarte J. 2008. Involvement of advanced glycation end products in the pathogenesis of diabetes complication: the protective role of regular physical activity. European Review of Aging Physical Activity 5(1): $17-29$.

[18] Moyers S. 1996. Garlic in Health, History and World Cuisine. Suncoast Press, St. Petersburg, FL:1-36.

[19] Nrashan T S, Kumar D, Kewal LS, Raisuddin A, Sahu P. 2010. Adverse health effects due to arsenic exposure, modification by dietary supplemnation of jaggey in mice. Toxicology and Applied Pharmacology 242(3): 247-255.

[20] Otsuka F, Ogura T, Kataoka H, Kishida M, Takahashi M, Mimura Y, Yamauchi T, Makino H. 2000. Differential effect of chronic inhibition of calcium channel and angiotensin II type-1 receptor on aldosterone synthesis in spontaneously hypertensive rats. Journal of Steroid Biochemistry and Molecular Biology 74(3): 125-136.

[21] Qureshi S, Shah AH, Tariq M, Ageel AM. 1989. Studies on herbal aphrodisiacsused in Arab system of medicine, American Journal of Chinese Medicine 17: 57-63.

[22] Rhiouania H, El-Hilalya J, Israili ZH, Lyoussia B. 2008. Acute and subchronic toxicity of an aqueous extract of the leaves of Herniaria glabra in rodents. Journal of Ethnopharmacology 118: 378-386.

[23] Schales O, Schales S. 1941. A simple and accurate method for the determination of chloride in biological fluids. Journal of Biochemistry 140: 879-884.

[24] Segal MA. 1955. A rapid electrotitimetric method for determining $\mathrm{CO}_{2}$ combining power in plasma or serum. American Journal of Clinical Pathology 25(10):1212-1216.

[25] Shoji N, Iwasa A, Jakemoto T, Ishida Y, Ohizuma Y. 1982. Cardiotonic principle of ginger (Zinigiber officinale Roscoe).Journal of Pharmaceutical Sciences 71: 1174-1175.

[26] Sogani RK, Katoch K. 1981. Correlation of serum cholesterol levels and incidence of myocardial infarction with dietary onlyand garlic eating habits, Journal of the Association Physicians of India 29(6): 443-446.

[27] Stewart J, Wood MJ, Wood CD, Mims ME. 1991. Effects of ginger on motion sickness susceptibility and gastric function. Pharmacology 42:111-120

[28] Sujatha R, Srinivas L. 1995. Modulation of lipid peroxidation by dietary componenets. Toxicology in vitro 9: 231-236.

[29] Sumiyoshi H. 1997. New pharmacological activities of garlic and its constituents (Review). Folia Pharmacological Japonica 110 (Suppl 1): 93-97.

[30] Vogel AI. 1960. A Textbook of Quantitative Inorganic Analysis. Longman Group Ltd.

[31] Zanchetti A, Stella A, Golin R. 1985. Adernergic sodium handling and the natriuretic action of calcium antagonists. Journal of Cardiovascular Pharmacology 6(7):194-198. 